\title{
PODMÍNKY PRO ROZVOJ KONGRESOVÉHO TURISMU V MORAVSKOSLEZSKÉM KRAJI
}

\section{OPTIONS FOR DEVELOPMENT OF CONGRESS TOURISM IN THE MORA VIAN SILESIAN REGION}

\section{Ing. Miroslava KOSTKOVÁ Ph.D. \\ ING. MILENA BOTLÍKOVÁ}

\author{
Katedra cestovního ruchu $\mid$ Department of Tourism \\ Obchodnクpodnikatelská fakulta v Karviné School of Business Administration \\ Slezská Univerzita v Opav门| Silesian University \\ $\bowtie$ Univerzitní nám. 1934/3, 73340 Karviná, Czech Republic \\ E-mail:kostkoval@opf.slu.cz, botlikova@opf.slu.cz.
}

\begin{abstract}
Anotace
Kongresový cestovní ruch pŚdstavuje relativnク novou a zhlediska ekonomiky významnou formu cestovního ruchu. Llánek pojednává o pŚedpokladech, pŚleǵitostech a rozvoji kongresové turistiky

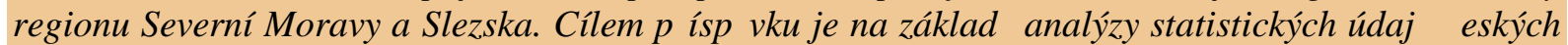
a svnových institucí a prostŚdnictvím komparace uvést moğné vývojové trendy a pŚleğitosti pro rozvoj kongresového turismu. Výsledkem jsou závny, které zdTrazRují jeho rostoucí význam a pŚleǵitosti v oblasti regionálního rozvoje a cestovního ruchu v Moravskoslezském kraji.
\end{abstract}

\section{Klị ová slova}

kongresový cestovní ruch, Moravskoslezský kraj, pŚedpoklady rozvoje cestovního ruchu v regionu

\section{Annotation}

Congress tourism is relatively new and in terms of economy important form of tourism. The article discusses the assumptions, opportunities and development of congress tourism in the Moravian Silesian region. The aim of this paper is to analyze statistical data from the Czech and world institutions and on the base of comparison to indicate the possible trends and opportunities, which is developed congress tourism. Resulting conclusion highlights the growing meaning of congress tourism in the field of regional development and tourism in the Moravian Silesian region.

Key words

congress tourism, Moravian Silesian Region, options of the regional tourism development

JEL classification: $M 21$

\section{Úvod}

Kongresový cestovní ruch pŚdstavuje formu cestovního ruchu, podstatou které je vým円ha vhleckých a odborných informací a poznatkT, spojena s poznáváním daného regionu a nabídkou doprovodných akcí. Je pokládán za nejresistentnநğ !̣́st cestovního ruchu, na jehoǵ rozvoji se dlouho neprojevoval

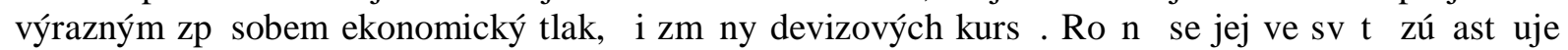
v prTmদư 4,5 mil. úl astníkT, pŚs $50 \%$ z nich zamíŚ do Evropy (Lertík, 2001). Hlavním motivem je pS̊dávání nových poznatkT, navázání obchodních kontaktT, nalezení Śggení problémT v daném oboru, nebo setkávání odborníkT ur! ité oblasti. 
Stále více si uv hlomujeme výhody, plynoucí z poŚidání kongresových akcí, které znamenají pro region zvýǵení daŔových pŚjmT, zamß̧tnanosti a návğhnosti daného místa, neboŠ spokojení úl astníci kongresových akcí se vracejí jako turisté.

PŚdstavuje pomクnn novou a z hlediska ekonomiky významnou formu cestovního ruchu, která je

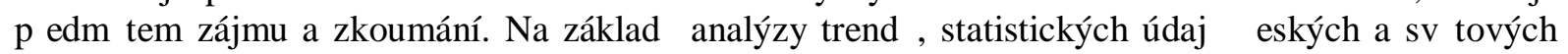
institucí a komparace lze uvést moǵné vývojové trendy a pŚleǵitosti pro rozvoj kongresového turismu regionu Severní Moravy a Slezska. Výsledkem jsou závĐy, které zdTrazŔují jeho rostoucí význam $\mathrm{v}$ oblasti cestovního ruchu a regionálního rozvoje $\mathrm{v}$ Moravskoslezském kraji. PŚ́spłyek byl zpracován v rámci Interního institucionálního projektu ISIP 2014 SU OPF.

\section{Cí a metody - vymezení a funkce kongresového cestovního ruchu}

Kongresový turismus prochází procesem zmゆ̧ kvantitativních a také kvalitativních. Za posledních 50 let se pol et kongresT a konferencí zvýğl tŚcetinásobnク ale pol et úl astníkT na jednu akci se stále sniğuje (podle ICCA v 60. letech se poḷ et úl astníkT pohyboval kolen 1200, dnes je to v prTm delegátT na 1 kongres).

Dochází k pŚnosu vĐlomostí a znalostí do praxe, díky !̣emuǵ tato forma cestovního ruchu hraje v soul asné dobワ významnou roli (Schreiber, 2002). Kongresový cestovní ruch (Meeting industry, kongresový prTmysl) je jedna ze sloǵek MICE (Meetings, Incentives, Conference and Exhibitions/Events). V souḷ asnosti se do MICE akcí pol ítají také akce incentivního, veletrğního a teambuldingového charakteru.

L̦SÚ vymezuje kongres/konferenci jako Ăformální setkání vĐğho poḷ tu lidí (od 100 osob) url itého odborného zamrśení, jehoǵ pŚedmhnem jsou prezentace, pŚdnáǵky, diskuse a konzultace. MT̛́ge se jednat o sjezd v'leckých pracovníkT, shromáǵdní diplomatických zástupcT jednotlivých státT apod. Typickým znakem kongresu/konference je doprovodný program (bývá spojen s exkurzemi, kulturním a spolel enským programem a gastronomickými akcemi).ñ

Kongresový cestovní ruch podle Orieg̉ky (2003) plní ve vztahu k jednotlivci i ke spoleḷ nosti nhkolik

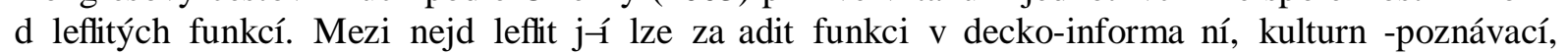
ekonomickou a v neposlední Śdn kongresový cestovní ruch pJsobí i jako významný faktor regionálního rozvoje. DTvody úl asti na konferenci podle Williama Cuttinga (Orieg̉ka, 2003) jsou:

- Vzdクávání ï osv hóení znalostí,

- inspirace ï nové nápady a setkávání s vedoucími postavami z oboru,

- benchmarking ï srovnání vlastní úrovnĐs ostatními,

- prezentace ï moǵnost dát o sobクvĐin svhu,

- spolel enská la ást ï setkávání lidí rTzných kultur.

Kongresový cestovní ruch má také ekonomický význam, lze jej povaǵovat za generátor finan! ních ziskT, za tvTrce pracovních pŚleǵitostí, efekt pŚmého obratu indikuje Śidu dalğch doplŔkových sluǵeb, které jsou s poŚídáním kongres], veletrh丁 a podobných akcí spjaty. Pro mß̧̧to, v nhnǵ se kongres koná, to znamená znal ný pŞjem do rozpol tu.

ř adí se k ekonomicky nejpŚnosnクğm formám cestovního ruchu. PrTmクnná útrata úl astníka kongresu, konference nebo výstavy bývá mnohem vyğğ, neǵ útrata blóného turisty. Vyğaduje ale ğroký okruh sluǵeb a aktivní pŚstup celého regionu. Ekonomický význam kongresového cestovního ruchu zdTrazḱuje také Indrová (2007):

- Dochází k plnhní specifických pracovních povinností, úl ast na n円on je v rámci pracovní doby,

- úl ast je hrazena zamßstnavatelem,

- výdaje úl astníkT jsou 2-3krát vyg̣g neǵ u jiných forem cestovního ruchu (podle CzechTourismu prTmクnná útrata na jednoho úl astníka se v Praze pohybuje kolem 6500 ï 10000 K!̣ ),

- konzumují se specifické sluğby vyğǵho standardu, obvykle komplexní balí| ek sluǵeb,

- má specifickou infrastrukturu,

- má specifickou sezónu (nej! astクi jaro, podzim), 
- realizace pŚváǵnクve velkých $m$ ß̧tech,

- má kladný vliv na propagaci a pozitivní image destinace.

Má specifickou sezonalitu - pŚspívá ke zvýġení návğßynosti v obdobích, která jinak nejsou vyugoita pro klasické formy cestovního ruchu. Vhğina kongresT se koná mimo sezónu, takǵe dochází k potlal ení sezónnosti, pŚnosem je rovnomßgné vytíǵení disponibilních kapacit.

Stát si poŚidáním velkých mezinárodních kongresT rovnhǵ upevŔuje svou prestiǵ Profesionálové kongresové a konferen! ní turistiky se shodují, ǵe jde o jedno z nejrychleji se rozvíjejících odvクví

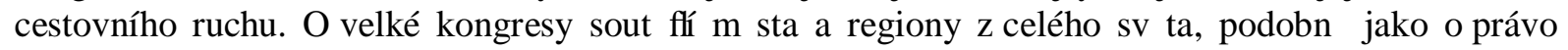
poŚidat olympijské hry a dalğ velké, svými synergiemi pro zemり a regiony komer!̣n npŚnosné události.

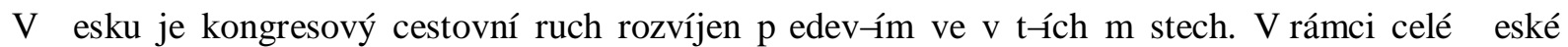
republiky vğak není potenciál kongresového cestovního ruchu dostatel nךvyuğit. Vzhledem k trendu sniǵování poḷ tu úl astníkT je moǵné vyuğ́t i menğch stŚedisek, která se mohou vyprofilovat jako místní kongresová centra. Tato profilace vğk vyğaduje investice do infrastruktury a lidských zdrojT (Václavínková et al., 2012).

\section{Statistické vykazování kongresové turistiky}

Postavení jednotlivých zemí, resp. mḩt na poli kongresového cestovního ruchu vychází z mezinárodních statistik UIA (Union of International Associations) a ICCA (International Congress \& Convention Association). Smyslem získávání a zpracování statistických informací je poznání, hledání tendencí ve vývoji a jejich vyuğití v praxi.

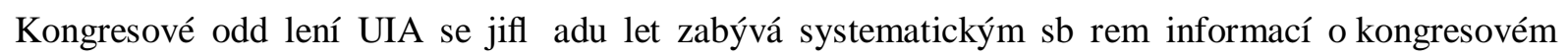
cestovním ruchu, které se objevují v Rol ence mezinárodních poŚidatelT (Yearbook of International Organizators) a v Mezinárodním kongresovém kalendáŚ (International Congress Calendar). Na jejich základநlze vytváŚet analýzy a prognózy dalğho vývoje.

Podle UIA $50 \%$ vg̉ech kongresT se odehrává v deseti zemích, které si na trhu kongresového cestovního ruchu udrǵují stabilní pozici (Singapur, Japonsko, USA, Belgie, Jiǵní Korea, Francie, Rakousko, Ǵanクsko, Nクnecko a Austrálie). Podle ICCA mezi TOP 10 nejvýznamnクğch kongresových mß̧t v roce 2012 patŚl Singapur, Brusel, VídeŔ PaŚǵ Soul, Tokio, Barcelona, KodaŔ Madrid a Londýn.

Dle údaj] ICCA pol et mezinárodních setkání za posledních 50 let celosvĐovクroste. Od roku 1963

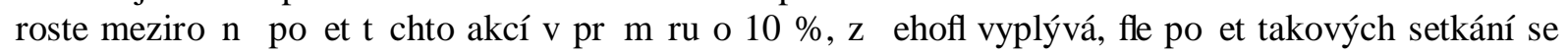
kaǵdých 10 let více neǵ zdvojnásobí. Gẹş́| ku TOP 10 zemí v poḷ tu poŚídaných mezinárodních setkání (podle L LUÚ) dlouhodobクvévodí Spojené státy americké s poḷ tem 4277 uspoŚídaných setkání v období 2008ï 2012. Dále v poŚdí je Nク̉necko (3 091), Ǵpanクsko (2 523), Spojené království (2 381), Francie (2 338), Itálie (2 199), L ína (1 685), Japonsko (1 591), Brazílie (1 534) a Nizozemsko (1 489).

Podle Beránka z Magconculting (2013) na poli kongresového cestovního ruchu zatím vévodí Evropa, v hg̉ina kongresT, semináŚT a dalğch setkání se odehrává (a do budoucna lze oḷ ekávat, ğe se bude odehrávat) v západní ḷ ásti evropského kontinentu, pozoruje se vğak vzestup asijských zemí.

\section{Podmínky kongresové turistiky v Leské republice}

Postavení Ĺeské republiky na trhu kongresového cestovního ruchu se po nedávném oslabení v roce 2008 zlepğije. L̦eská republika se thğ stabilnímu zájmu kongresového turismu, v roce 2012 se pol tem akcí umístila na 31. místクve sv hn Podíl L̦eské republiky na sv Đovém kongresovém cestovním ruchu vğkk nedosahuje ani $1 \%$. Naproti tomu Praha se v roce 1999 navrátila mezi prvních dvacet 


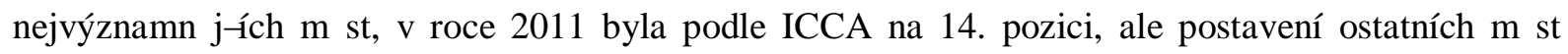
L eské republiky na tomto trhu se výraznクzhorğlo.

Podle L̦SÚ se v roce 2012 v L̦R konalo 11547 kongresových akcí s poḷ tem 1535597 úl astníkT, z toho v Praze 4264 akcí s poḷ tem 671812 úl astníkT (27\% z celkového poḷ tu akcí s prTmm lným poḷ tem 694 úl astníkT na akci).

Lesko disponuje dobrým potenciálem pro poŚdání tḩhto akcí, kraje nabízí mnoǵství kulturních a pŚrodních atraktivit a dostal ující konferen! ní kapacity (Libová, Jade, 2009). Nag̉e zemつje dobŚs dostupná (nachází se zde ph mezinárodních letiğš dopravní infrastruktura je dostal ující), p§́dstavuje destinaci s pozitivní image, je povaǵována za bezpel nou a ekonomicky, politicky a kulturnクvysp Đou zemi.

Komplexní konferen! ní centra tvoŚ 63 \% z celkové kapacity konferen! ních prostor, 18 \% pŚpadá na 4 hv łzdil kové a $13 \%$ na 3 hvłłdil kové ubytovací zaŚzení. V roce 2011 se v L̦R konalo 51,5\% MICE

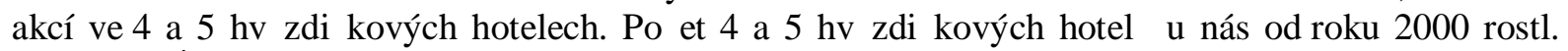
Podle L̦SÚ v roce 2000 bylo u nás evidováno 152 hotelT tḩhto dvou tŚd, z toho 53 v Praze (v Ostravクpouze 8 ! tyŚınłdil kových hotelT), v roce 2011 jich bylo jiǵ celkem 517 (z toho 213 v Praze a 27 v Ostravn. V hromadných ubytovacích zaŚzeních se konají spíge menğ kongresové akce (pro 50 ï 150 úl astníkT).

$25 \%$ konferen! ních sálT u nás má kapacitu 50 ï 90 míst, 20 \% 100 ï 199 míst. Nad tisíc míst má jen $5 \%$ konferen! ních center. Nejvíce kongresT pŚedstavují konferen! ní akce pro 100 - 199 úl astníkJ. V roce 2011 byl zaznamenán nejvýraznクg் nárTst v kategorii mítinkT s poḷ tem 150 ï 250 úl astníkT. Na 1. míst门 jsou korporátní konference/setkání, následovány asocial ními konferencemi/kongresy. Jedná se pŚdevğm o akce mezinárodního významu, tematicky jsou zam垖é na IT technologie, lékaŚské vhly a farmacii, obchod, prTmysl, technologie a ekonomii.

Nejvíce úl astníkT kongresT, konaných v L̦R je podle statistik z ḶR, Velké Británie, USA, N円necka, Francie, Rakouska a Nizozemí, toto sloǵení je v prTbクhu posledních let pomクnnkonstantní.

Nejvíce akcí se dle sv hového trendu koná v mḩ́ci záŚ, Śjnu, listopadu, ale také v bŚgznu. L̦eská republika odpovídá evropskému trendu, kdy mezi nejslabơ mß̧íce nepatŚ zimní mß̧íce, ale naopak letní.

Výraznクdominují jednodenní akce. Podle ICCA prTmクnná délka trvání byla v roce 2013 - 2,31 dne, $\mathrm{v}$ roce $2012-2,06$ dne a $\mathrm{v}$ roce $2011-3,8$ dne.

Za nejvýznamnクğ kongresové místo mezinárodního významu v L̦R lze povaǵovat pouze Prahu. Praha se v oblasti sluǵeb kongresového turismu výraznクposunula vpŚ́d a v soul asné dobク se Śdí mezi evropskou ǵpil ku. Praha disponuje nejlepg்m potenciálem pro kongresový cestovní ruch, nalezneme zde $31 \%$ konferen! ních center (232 z 852), coǵpŚdstavuje $37 \%$ konferen! ních kapacit v LR. V roce 2013 získala cenu Meeting Star v kategorii ÂNejlepğ kongresová destinace stSední a jihovýchodní Evropyñ Podle Jaromíra Beránka z MagConsultingu (2013) nelze ol ekávat, ǵe by Praha hostila velké kongresy a meetingy. Její potenciál vyugóvají poŚadatelé zejména stŚdních a menǵ̛ch setkání. Pokud vğak jde o doplŔkové aktivity, Praha se coby místo pro setkání jeví jako plnク vyhovující destinace. V Praze se konalo mnoho významných mezinárodních konferencí (zasedání Mezinárodního mnového fondu a Skupiny Svßové banky, Summit NATO, zasedání Mezinárodního olympijského výboru, Microsoft Security Summit aj).

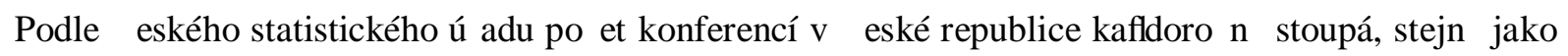
poḷ et úl astníkT na thhto akcích (v roce 2009 byl zaznamenán pol et akcí $9411 \mathrm{~s}$ pol tem úl astníkT 1192 909, v roce 2012 byl pol et akcí 11547 s poḷ tem úl astníkT 1350 459).

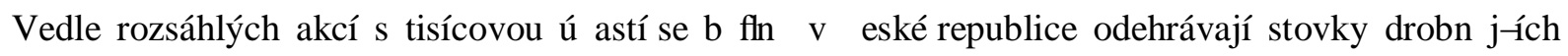
konferencí a kongresT. Mnoho !̣ eských destinací má pro realizaci MICE v soul asnosti podobné 
podmínky. U vhg̈ny kraj丁 Ḷeské republiky v rozvojových dokumentech je nastínhn potenciál a jsou vymezeny aktivity, které by $\mathrm{m} \eta \mathrm{y}$ vést ke zlepġení jejich pozice $\mathrm{v}$ oblasti kongresového cestovního ruchu, s uceleným systémem propagace a existují organizace, které podporují prosazení daného regionu v oblasti kongresového cestovního ruchu. Od roku 2009 funguje projekt Czech convention bureau, kterého cílem je podpoŚt rozvoj kongresového cestovního ruchu v regionech Ḷeské republiky.

\section{Vývoj segmentu MICE v Moravskoslezském kraji}

Moravskoslezský kraj splŔuje nárol né podmínky pro konání nejrTzn円ğch akcí v segmentu meeting industry a incentivních pobytT. ProstŚednictvím krajského $m$ 乃sta má kraj potenciál i pro kongresovou turistiku. Strategická poloha v blízkosti polské a slovenské hranice vytváŚ z Ostravy mhto, které disponuje zlepġijící se nabídkou pro profesní cestovní ruch. PŚtomnost zajímavých pŚrodních oblastí, specifická architektura, dobrá dopravní dostupnost (dálnice D47, v Moğnov u Ostravy se nachází jedno z významných mezinárodních letiğš Ḷeské republiky), kvalitní kongresová infrastruktura, pŚtomnost mezinárodních hotelových Sethec], dostatel ná hotelová kapacita a kvalitní sluğby v odpovídajícím standardu (12 000 míst pro MICE segment, 5500 lTǵek), významná prTmyslová základna a vĐlecké odborné zázemí místních univerzit. Ostrava byla v Návrhu kategorizace kongresových $\mathrm{m} \bigcap_{\mathrm{t}} \mathrm{zaŚ}$ zena mezi m円sta první volby.

V Moravskoslezském kraji jiǵ rok p丁sobí Moravskoslezské Convention Bureau, které se zabývá rozvojem a propagací kongresového turismu v kraji. Podle $\mathrm{n} \bigcap$ kongresová a incentivní turistika vykazují vzrTstající tendenci (Tab.1). O Ostravu a Moravskoslezský kraj je mezi kongresovými turisty zájem.

Tab. 1: Konference v hromadných ubytovacích za ́́zeních

\begin{tabular}{|c|r|r|r|r|}
\hline & \multicolumn{2}{|c|}{ Leská republika celkem } & \multicolumn{2}{c|}{ Moravskoslezský kraj } \\
\hline Rok & Pol et konferencí & Pol et úl astníkJ & Pol et konferencí & \multicolumn{1}{c|}{ Pol et úl astníkT } \\
\hline 2006 & 3230 & 655227 & 170 & 31694 \\
\hline 2007 & 3518 & 702586 & 264 & 45640 \\
\hline 2008 & 3832 & 761901 & 369 & 71501 \\
\hline 2009 & 9411 & 1192909 & 710 & 98337 \\
\hline 2010 & 10146 & 1295287 & 1008 & 135478 \\
\hline 2011 & 10601 & 1350459 & 1078 & 189059 \\
\hline 2012 & 11547 & 1535597 & 1009 \\
\hline
\end{tabular}

Zdroj: Zpracováno podle CzechTourism: Analýza kongresového a incentivního segmentu cestovního ruchu,

Z Oficiální databanky kongresové a incentivní turistiky je patrné, ğe se v Moravskoslezském kraji nalézá 49 zaŚzení, vhodných pro konání akcí kongresového cestovního ruchu (Tab.2).

Tab. 2: Moravskoslezský kraj ï kapacity pro poŚídání akcí MICE

\begin{tabular}{|c|c|l|c|c|c|c|}
\hline hotely **** & hotely*** & $\begin{array}{l}\text { konferen! ní } \\
\text { centrum }\end{array}$ & $\begin{array}{l}\text { kulturní } \\
\text { centrum }\end{array}$ & výstaviğr. & $\begin{array}{l}\text { sportovní } \\
\text { hala }\end{array}$ & cekem \\
\hline 12 & 22 & 3 & 10 & 1 & 1 & 49 \\
\hline
\end{tabular}

Zdroj: Zpracováno podle CzechTourism: Analýza kongresového a incentivního segmentu cestovního ruchu,

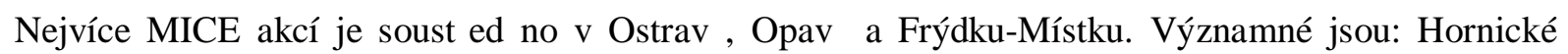
muzeum OKD a Landek Park v Ostravク mající kapacitu spojených sálT 1000 míst, nové kongresové centrum hotelu Clarion Congress Hotel (1 600 míst), Mamaison Imperial Hotel (550 míst), kongresové centrum Gong (1 500 míst). Dalğmi zaŚzeními, nabízející 400 a více míst jsou Národní dTm (Frýdek-Místek, 440), Kulturní dTm Frýdek (400) a DTm kultury Bílovec (400), Rotschild Palace (v souḷ asnosti v rekonstrukci), DTm kultury m\$ta Ostravy (1000 míst). 
Nové Trojhalí Nová Karolína s kapacitou 800 míst se Śdí k nejvクğm kongresovým zaŚzením

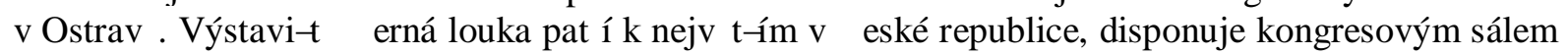
s kapacitou 300 míst.

Podle poḷ tu akcí kongresového cestovního ruchu, konaných v hromadných ubytovacích zaŚzeních je Moravskoslezský kraj na tŚ́tím míst门 v L esku. V kraji se dle L̦SÚ konalo v roce 2012 ve 14 hromadných ubytovacích zaŚzeních 1078 akcí s celkovým poḷtem 189059 úlastníkT (175 úl astníkT na 1 akci). Tyto hodnoty pŚedstavují pom ĐnĐvýrazné zvýǵení oproti roku 2006.

Potenciál pro kongresový cestovní ruch je vyzdvihován v Marketingové strategii rozvoje cestovního ruchu v turistickém regionu Severní Morava a Slezsko, v ROP NUTS II a také v Koncepci rozvoje cestovního ruchu statutárního m円̧̧ta Ostravy z roku 2004. Ostrava je zde definována jako Ăobchodní centrum regionu, nabízející výjime! né podmínky pro profesní cestovní ruchñ Vize mß̧̧ta Ostravy sdクjuje, ǵe v roce 2015 by $\mathrm{m}$ ha být Ostrava (resp. Ostravsko) Ătraktivní a vyhledávanou destinací profesního cestovního ruchu, nabízející výjimel né zázemí pro konání kongresT, konferencí, výstav a veletrhT, firemních a obchodních jednání, výjimel nost tohoto zázemí by mПa vycházet z vyugoití silných stránek a industriální historie Ostravy a její blízkosti k pŚrodním perlám regionu (Beskydy, Jeseníky, PoodŚ).ñ

\section{Výsledky - trendy a pSileốtosti kongresového turismu}

Konference, kongresy a dalğ akce $\mathrm{v}$ posledních letech kopírují pokles ekonomiky, a to s ur! itým zpoǵdhím, v návaznosti na velikost jednotlivých akcí. Zatímco menğ akce jsou pŚpravovány v Ś́du mḩíc丁, velké akce poŚ̊datelé pŚpravují s pŚdstihem nholika let.

Prognózy dalğho vývoje kongresové turistiky lze podle provedených prTzkum丁 oznal it za pŚ́znivé. Tempo rTstu kongresového turismu by mno víceménク kopírovat tempo celkového ekonomického rozvoje - vǵdy vğk s malým l asovým odstupem (u menğch kongresT dva roky, u velkých kongres丁 aǵ! tyŚ roky).

Na základクúdajT UIA lze do budoucna pŚdpokládat mírný pokles kongresT v tradil ním pojetí. Stále více se rozvíjí elektronická forma kongresT. I kdyǵ je jejich pol et stále nízký, vykazuje rostoucí tendenci. Do budoucna se poḷítá jak s organizací samostatných elektronických kongres T, tak s rozġśśním tradi! nクpojatých kongres] o tuto dimenzi. Mnoho expert丁 na kongresový cestovní ruch pŚdpokládalo celosv Đový pokles poḷ tu poŚídaných kongresT a dalğch akcí v návaznosti na nová elektronická média. Tento pokles se zatím nepotvrdil, pŚssto lze oḷ ekávat, ǵe v prTbநhu nhkolika málo

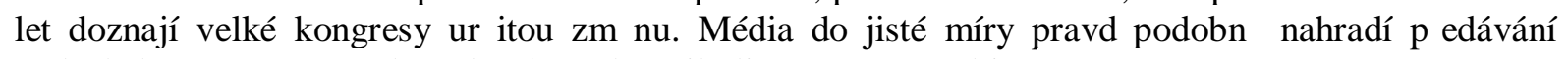
v'leckého poznání, avğak osobní kontakty nikoliv (Mag Consulting, 2013).

Podle ICCA z výǵe uvedeného lze ur! it tyto trendy MICE:

- Mezinárodní konferen! ní trh je stále více hnán poǵadavky spotŚ́bitele (trh zákazníka), organizátoŚ cht円í snígit své náklady, vyhnout se skrytým nákladT̄m a za své peníze získat co nejlepğ hodnotu.

- Délka mezinárodních konferencí pozvolna klesá, ale letnost jejich konání znaḷnn stoupá. Spole! nosti cht'ní snígit dobu, kterou jejich pracovníci stráví na konferencích, a tím také snígit své náklady.

- Na významu nabývá výstavní komponent v ğğch konferencí, ğádá se, aby konferen! ní prostory zahrnovaly vnğg výstavní prostory.

- Úl astníci konferencí ḷastクi cestují s doprovodem, se svými partnery, l i s rodinou. Doprovázející

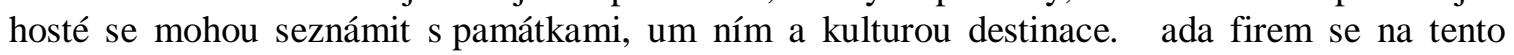
segment specializuje.

- Pol et ǵenských úl astnic konferencí neustále roste a konference se mén円 orientují výhradnク na muǵe.

- Bezpel nost se pro poŚdatele konferencí i úl astníky stala klíl ovou otázkou pŚ výbクuu místa konání. 
- Vyuǵivá se aplikace moderních informal ních technologií (on-line rezervace a registrace) pro potŚby zkracování a p\$́dstihu plánu mezinárodních akcí.

- Proffesional Congress Organizers pouğivají internet jako primární zdroj informací nabídky míst pro konání konferencí.

Z prTzkumu významných ḷ eských ubytovacích zaŚzení, specializovaných na kongresový segment vyplývá, ǵe sluğby pro MICE klientelu se mohou stát významnou konkuren! ní výhodou (Vampulová, 2013). V souḷ asnosti z dTvodu pŚ́visu nabídky konferen! ních kapacit nad poptávkou dochází $\mathrm{k}$ výraznému cenovému dumpingu, coǵ vede k poklesu cen, s negativním dopadem na kvalitu poskytovaných sluǵeb, sniǵování hodnoty produktu a následnクtaké destinace.

V dTsledku vývoje je potŚbné zabývat se efektivitou pŚnosu informací a znalostí, podporou kreativity na akcích i dlouhodobými ekonomickými výhledy a strategickým plánováním (L̦uka, 2012). Podpora kongresovému prTmyslu souvisí i podporou místních PCO a destinaḷ ních spole!̣ ností tak, aby kongresy a konference svým pŚnosem z obratu pomohly také místní ekonomice. Multiplikal ní efekt $\mathrm{z}$ tohoto ! istého prTmyslu je významný - L̦ SÚ uvádí pŚnos do ekonomiky zemクcca 20 mld. K! rol $\mathrm{n} n$

Z komparace silných stránek kongresové turistiky Vídnク jako evropského kongresového lídra, Prahy a Ostravy se potvrzují dobré pŚdpoklady pro rozvoj kongresové turistiky na Ostravsku (Tab.3).

Pro rozvoj kongresové turistiky je potŚebné eliminovat slabé stránky regionu Severní Moravy a Slezska, mezi které patŚ pŚtrvávající trend jednodenních návğh a s tím související nízké vyuğivání ubytovacích kapacit, negativní hodnocení dopravní infrastruktury a dostupnosti regionu hromadnou dopravou a naopak posílit vnímání regionu jako vhodného k vícedenním pobytTm v souvislosti s pŚznivým ğivotním prostŚdím, vyuğ́t rozg̣śsí nabídky kulturního a spolel enského vyğití, propagovat turistické kulturní atraktivity a pŚlákat tak návg̉Đıníky z vigğch vzdáleností.

Tab. 3: Komparace silných stránek kongresového turismu Vídn円 Prahy a Ostravy

\begin{tabular}{|c|c|c|}
\hline VídeR & Praha & Ostrava \\
\hline $\begin{array}{l}\text { Obsazuje tradiḷn npŚední místa } \\
\text { v ǵebŚ! ku ICCA. }\end{array}$ & $\begin{array}{l}\text { Dlouhá tradice v poŚdídání } \\
\text { významných a prestiğních } \\
\text { kongresových akcí. }\end{array}$ & $\begin{array}{l}\text { Roḷ ní nárTst v poḷ tu konferen! ních } \\
\text { kapacit a poŚídaných } \\
\text { konferen! ních akcí o } 20 \% \text {. }\end{array}$ \\
\hline $\begin{array}{l}\text { M\şto ohleduplné k ğivotnímu } \\
\text { prostŚdí, certifikát AGreen } \\
\text { Meetingñ }\end{array}$ & Neuvedeno. & $\begin{array}{l}\text { Zlepǵající se pél e o ǵivotní } \\
\text { prostŚdí a pél e o památky } \\
\text { a turistické atraktivity. }\end{array}$ \\
\hline $\begin{array}{l}\text { Univerzitní mßsto, mßsto vhly } \\
\text { a vývoje. }\end{array}$ & $\begin{array}{l}\text { Univerzitní mß̧to, mß̧to vłly } \\
\text { a vývoje. }\end{array}$ & $\begin{array}{l}\text { Univerzitní mßsto, mß̧to vłly } \\
\text { a vývoje. }\end{array}$ \\
\hline $\begin{array}{l}\text { Disponuje bohatou kongresovou } \\
\text { infrastrukturou. }\end{array}$ & $\begin{array}{l}\text { Rozvinutá kongresová } \\
\text { infrastruktura. }\end{array}$ & $\begin{array}{l}\text { Rozvíjející se kongresová } \\
\text { infrastruktura. }\end{array}$ \\
\hline Mhsto s vysokou kvalitou ǵivota. & $\begin{array}{l}\text { Vysoká kvalita nabízených sluǵeb } \\
\text { za pŚjatelné ceny. }\end{array}$ & $\begin{array}{l}\text { Pozitivní vnímání cenové relace } \\
\text { sluǵeb, nízkonákladový region. }\end{array}$ \\
\hline Bezpeḷ né mßșto. & Bezpeḷ né mßsto. & Bezpel né mßsto. \\
\hline Alokace v srdci Evropy. & $\begin{array}{l}\text { Strategická poloha v srdci Evropy, } \\
\text { s dobrou dopravní dostupností. }\end{array}$ & $\begin{array}{l}\text { Strategická poloha Ostravy } \\
\text { v blízkosti hranic s Polskem } \\
\text { a Slovenskem. }\end{array}$ \\
\hline $\begin{array}{l}\text { Mク̧to kultury, památek a hudební } \\
\text { metropole, plná umПjeckého } \\
\text { bohatství. }\end{array}$ & $\begin{array}{l}\text { Bohatá historie, kultura, } \\
\text { architektura a mnoho turistických } \\
\text { atrakcí. }\end{array}$ & $\begin{array}{l}\text { Rostoucí spokojenost } \\
\text { se spolel enským vyğitím } \\
\text { a nabídkou volnoḷ asových aktivit. }\end{array}$ \\
\hline
\end{tabular}

\section{Závn}

Situace v kongresovém cestovním ruchu je z celosvhového hlediska stabilní. RTsty a poklesy sledovaných hodnot na jednotlivých kontinentech, zemích a mḩtech nejsou nijak výrazné. Rozvoj

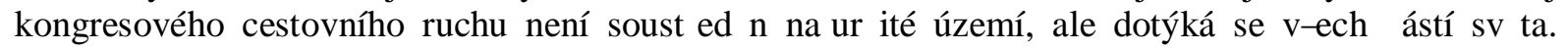
Velké mezinárodní kongresy mohou výrazn円 ovlivnit celé národní hospodáŚství hostitelské zemク 
Jejich finan! ní dopad pocítí jak soukromý, tak státní sektor. PoŚidání mezinárodních kongresT je velmi prestiǵní záleǵitost nejen pro mß̧to, ale pro celou zemi (Haval, Jánog̉ka, 2008).

Prognózy dalğho vývoje kongresové turistiky lze podle provedených prTzkumT oznaḷ it za pŚznivé. Naǵe zemク vstoupila na kongresový trh teprve v 90. letech minulého století. L eské republice se podaŚlo pŚdevğm díky Praze dostat mezi významné kongresové destinace.

Moravskoslezský kraj má vhodné podmínky pro rozvoj MICE, snaği se neustále následovat trendy a

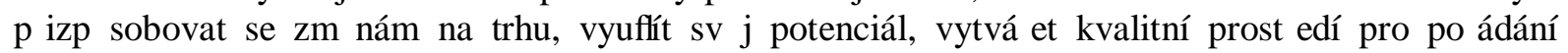
kongresT a do budoucna existuje reálný pśdpoklad, ǵe svou pozici na trhu MICE jeġクvíce posílí.

\section{Literatura}

[1] ARR, (2006). Marketingová strategie rozvoje cestovního ruchu v turistickém regionu Severní Morava a Slezsko: Ak!̣ní plán. Ostrava: Moravskoslezský kraj. [cit. 2014-1-15]. Dostupné <http://verejnasprava.krmoravskoslezsky.cz/rr_12.html>.

[2] BERÁNEK, J., (2008). Základy cestovního ruchu, stravovacích sluǵgb a lázeŔství. 1.díl. Praha: Vysoká gkola cestovního ruchu a teritoriálních studií. ISBN 978-80-86724-35-5. p.106.

[3] CzechTourism a kongresová turistika v r. 2004. [online]. [cit. 2014-01-19]. Dostupné z: <http://www.czechtourism.cz/index.php?show=023278>.

[4] CzechTourism, (2008). QCM. CzechTourism - podporujeme incomingový cestovní ruch. Kongresová turistika: Praha na 12. míst ] [online]. 2003, l, erven 2008 [cit. 2014-01-15]. Dostupné z: $<$ http://www.czechtourism.cz/index.php?show=055001032>.

[5] LERTÍK, M., (2001). Cestovní ruch - vývoj, organizace a Ś́zení. Praha: OFF, s.r.o. ISBN 80-238-6275-8. p. 352.

[6] Ĺeský statistický úŚd, (2012). Statitická roḷenka Moravskoslezského kraje 2012. Ostrava : Leský statistický úŚid. ISBN 978-80-250-2269-6.

[7] LUKA, P., (2011). Základy teórie, metodológie a regionalizácie cestovného ruchu. Preg்ov: Preg்ovská univerzita. ISBN 978-80-55-0471-1. p. 93.

[8] HAVAL, M., JÁNOĠKA, K., (2008). Vademecum pro profesionály ve sunクMICE, Díl I. - PrTvodce sv ク †em MICE. Praha: Ministerstvo pro místní rozvoj L̦R. p. 56.

[9] INDROVÁ, J., (2007). Mezinárodní cestovní ruch: vybrané kapitoly. Praha: Oeconomica. ISBN 978-80245-1287-7. p. 92.

[10] Kongresová turistika vOstrav $\quad$ [cit. $2014-01-31] . \quad$ Dostupné <https://convention.ostrava.cz/images/files/TZ-\%20Kongresov\%C3\%A1\%20turistika.pdf>

[11] LIBOVÁ, A., JADE, S., (2009). Marketing Plan Prague Convention Bureau 2009. Praha: Prague convention bureau. pp. 13.

[12] Mag Consulting., (2006). Kongresový a incentivní cestovní ruch. Praha: Mag Consulting. ISBN 80-8672420-4. p.79.

[13] Mag.Consulting, (2000). Kongresový cestovní ruch. COT Business [online]. [cit.2013-3-15]. Dostupné <http://www.cot.cz/data/cesky/00_09/9_stat_1.htm> 4.9.2008 [cit. 2014-01-31].

[14] MagConsulting, (2008). Charakteristika a hodnocení potenciálu cestovního ruchu Moravskoslezského kraje a jeho subregionT. COT Business [online]. [cit. 2014-01-31]. Dostupné z: <http://www.cot.cz/index.php?page=200\&jazyk=1\&id=1040812062>.

[15] ORIEĠKA, J., (2004). Kongresový cestovní ruch. Praha: Idea Servis. ISBN 80-85970-45-7. p. 139.

[16] PÁSKOVÁ, M., ZELENKA, J., (2002). Výkladový slovník cestovního ruchu. Praha: MMR. p.448.

[17] SCHREIBER, M. T., (2002). Kongress- und Tagungsmanagement. Auflage. München, Wien: Oldenbourg. ISBN 80-238-6275-8. p. 583.

[18] The International Association Meetings Market. Statistics Report 2010. Dostupné z: $<$ http://www.iccaworld.com/dcps/doc.cfm?docid=1130>.

[19] VÁCLAVÍNKOVÁ, K., KOSTKOVÁ, M., BOTLÍKOVÁ, M., (2012). Analysis of the impact of selected variables on the availability of accommodation facilities. In Mathematical Methods in Economics 2012. Karviná: Slezská univerzita v Opavク ISBN 978-80-7248-779-0. pp. 950-956.

[20] VAMPULOVÁ, M., (2013). Kongresová turistika. COT Business, 11/2013, pp.24-25. 